\title{
Political perspectives of relationship networks to internationalization of firms in an emerging economy
}

\author{
Jefferson Marlon Monticelli ${ }^{1 A}$, Ivan Lapuente Garrido ${ }^{A}$ and Sílvio Luís de Vasconcellos ${ }^{B}$ \\ ${ }^{A}$ Universidade do Vale do Rio dos Sinos - UNISINO/RS, São Leopoldo, RS, Brasil \\ ${ }^{B}$ Universidade do Vale do Itajaí, Biguaçu, SC, Brasil
}

ARTICLE DETAILS
Article history:
Received November 11, 2016
Accepted July 24, 2017
Available online in August 31, 2017
Double Blind Review System
Scientific Editor
Ilan Avrichir

Keywords:

Relationship networks

Neo-institutional theory

Political perspective

Internationalization

Emerging countries

\begin{abstract}
The neo-institutional theory has been used to explain inter-organizational networks related phenomena from the economic and sociological perspectives. The political perspective has not been often used to study institutional contexts of networks. We aim to analyze the decision-making of the formal institutions in the internationalization process of firms in an emerging economy from a political bias. For the empirical field of study, we considered the Brazilian wine industry. Starting from a case study with twentythree interviews with representatives of wineries and entities of this industry, our paper furthers the understanding of how institutions influence the internationalization of firms in an emerging economy. Based on the political perspective of the neo-institutional theory, our study describes how institutions, mainly the government, can influence an industry. Government cannot afford resources to benefit or protect all the industries, as well as cannot provide incentives to all firms, and those that are supported will lose competitiveness. For the firms, the choices are based on trying to achieve economic advantages through political influences. For the institutions, the choices are based on political influences considering institutional strategies.
\end{abstract}

C 2017 Internext | ESPM. All rights reserved.

\section{INTRODUCTION}

Relationship networks was once a hot topic (Jarillo, 1988). Over the past decades, it has derived into several research focuses: alliances (Gulati, Nohria, \& Zaheer, 2000), social networking (Granovetter, 1973; Burt, 1992), learning (Anand \& Khanna, 2000), innovation (Pittaway, Robertson, Munir, Denyer, \& Neely, 2004), and governance (Provan \& Kenis, 2007). However, there are very few theories related to decision-making, ethics, and motivation in the institutional context of inter-organizational networks (Cropper, Ebers, Huxham, \& Ring, 2014). Networking may be contingent to "institutions such as the legal system, banking and finance system, education system, political system, and structure of the labor market" (Minh \& Hjorts $\varnothing$, 2015, p. 212). Governments may play a role in stimulating institutions that positively influence firms towards

\footnotetext{
${ }^{1}$ Corresponding author: E-mail jefffmarlon@hotmail.com
}

networking strategies (Edwards, Delbridge, \& Munday, 2005). On the other hand, inadequate laws may hinder the strategic networks' development. In addition, there are few studies and discussion about how and why businesses are involved with politics (Grant, Coen, \& Wilson, 2010) with rare exceptions as Sena, Lana, Marcon, and Bandeira-De-Mello (2016), Marcon, Lazzarini, Musacchio, and Bandeira-DeMello (2015), Brey, Camilo, Marcon, and Bandeirade-Mello (2014), and Musacchio, Lazzarini, and Aguilera (2015). At the most, economic theories identify the impact of the decision in some industries, as the neo-institutional theory, that indicates which industries have more influence on governments (Milner, 1997; Frieden, 1991). The neo-institutional theory with the economic (North, 1990) and sociological (DiMaggio \& Powell, 1983; Scott, 2001) perspectives has explained the inter-organizational networks related phenomena. More recently, the 
neo-institutional theory has been used combined with the industry-based and the resource-based views. This combination is defined as the institutionbased view (Peng, 2002). This perspective has been directed, mainly, to understand how the institutional mechanisms of emerging economies work and influence the performance of the firms with the other counterparts. However, in none of these theoretical perspectives, there is a prevalence of the political perspective of the neo-institutional theory.

In this paper, we aim to analyze the decisionmaking of the formal institutions in the internationalization process of firms located in an emerging economy under a political bias. For the empirical field of study, we considered the Brazilian wine industry - specifically the wineries in the South of Brazil, the largest producer and exporter of Brazilian wine. Nevertheless, in an emerging economy, wineries do not represent the traditional internationalized industry. Our thesis is that institutions, from a political perspective, can influence an industry through the government. In emerging economies, the government has a bigger influence on the market structure, due to market imperfections or ideologies and political strategies (Cuervo-Cazurra, Inkpen, Musacchio, \& Ramaswamy, 2014) through protectionist measures or providing resources to the firms. Firms that do not benefit from these measures lose competitiveness. Firms must adjust to the development of multi-level systems of government, with political settings being one of the strongest influences on how firms develop their strategies. Winery firms have different sizes and experiences. In addition, wineries need formal institutional support to search for external markets, from the Brazilian Agency of Promotion of Exports and Investments (Apex-Brasil) and the Brazilian Wine Institute (Ibravin). Thus, this paper presents the guiding question: How do formal institutions make decisions to stimulate the internationalization of firms from an emerging economy? We considered the network of firms as an analysis unit, in order to establish an interaction between the studies of network theory and neo-institutional theory from political and economic tendencies.

As the main contributions, our paper furthers the understanding of how institutions influence the internationalization of firms in an emerging economy. Our study describes the background of the wine industry, by presenting the formal institutions in the political perspective of neo-institutional theory, whether they are representative entities from the industry or wineries, regardless their sizes and degree of internationalization. In this scope, our study is justified by the relevance of the industry. According to the representative of the Brazilian Agency of Promotion of Exports and Investments - Apex-Brasil -, it has grown because of the project Wines of Brasil, which is one of the most successful projects among the more than 80 ones fostered by this entity. Moreover, the visibility of this project has furthered the socio-economic development of the region. In this paper, we address the theoretical assumptions supporting the neo-institutional theory from the economic and political power perspectives. Then, we describe the methodological aspects of the research design and detail the wine industry while contextualizing it in the international and domestic scene. Afterward, we identify wineries and entities that comprise the wine industry in Brazil. Next, we discuss the role of Wines of Brazil from a political bias. Finally, we present the conclusions of our research and indicate new issues to investigate.

\section{THEORETICAL BACKGROUND}

In this study, networks are analyzed as complex relationships between firms from a political perspective. In the political perspective, institutions carry the legacies of political, social, and historical forces, forming institutional arrangements according to their temporal path (Theilen \& Steinmo, 1992). The political institutionalists analyze the political formal institutions, legal codes, administrative norms, rules, and laws (Scott, 1995). In the economic perspective, we can highlight the idea of property right, the efforts to reduce transaction costs, and the actions of regulatory agencies (Hall \& Taylor, 1996). From a strategic view, networks are firms that can be used by managers or entrepreneurs to make their firms more competitive in the long run, aiming at a competitive advantage (Jarillo, 1988). Our purpose is to integrate networks, considering them as power sources that can interfere with political and economic decisions. In the following, we present economic and political perspectives of the networks, by using institutions as background.

\subsection{Networks from the economic perspective of the neo-institutional theory}

Government policies are influential by providing economic incentives, creating protection 
mechanisms in the domestic market (Sheth, 2011), besides driving the internationalization process of firms (Ramamurti, 2008). As firms strategically exploit the institutions to extract benefits (Martin, 2014), institutions generate restrictions on firms to reach their goals. These restrictions occur due to norms, requirements, and contractual mechanisms (Dunning \& Lundan, 2008). This highly competitive environment motivates firms to enhance their performance, in order to ensure their survival or rewards (North, 1990). The institutions are more restrictive than inclusive. They impose control, limits, norms to individuals and organizations. Those that do not comply with the institutions are no longer legitimized and "are excluded from the game, because they are not willing to play by the rules of the house."

According to North (1990), institutions play a vital role in the economy of any nation as institutions reduce uncertainty and become a reference to individuals. When institutions are inefficient, or the property rights are not guaranteed, an unfavorable environment for the success of these countries is identified. This institutional framework is more visible in emerging countries due to political and economic institutions that discourage productive activity. The level of political instability, government effectiveness and bureaucracy, quality of the regulatory system, the legal system predictability, and control of corruption are examples of this scenery (CuervoCazurra \& Genc, 2008).

In emerging markets, several factors are susceptible to the influence of the institutions. Economic and financial institutional risks implicate high levels of economic instability, exchange rate volatility, inefficiency of the capital market, and high inflation rates. It reflects on the investment levels of the firm, the market value, and the compliance of the consumer market (Banerjee, Banerji, Duflo, Glennerster, \& Khemani, 2006).

We evidenced the institution relatedness, i.e., the degree of the institutional relationship established between a firm and the institutions of a country (Meyer \& Peng, 2005). Typically, in emerging economies, relationships occur with great asymmetry of information, high costs of the transaction, based on political connections, reputations, and informal relationships, stimulating a diversification of products aiming to minimize risks. In developed countries, there are inverse characteristics that stimulate a reduction in the line of products of the firm, which in turn will base its source of competitiveness in the productive efficiency or through scope economies (Meyer \& Peng, 2005).

Child and Rodrigues (2005) emphasized the role of the government in promoting the internationalization of firms, especially in emerging economies. Most of the advantages of these firms in the domestic market (low operating costs, distribution systems, brands, customer, and government relations) are not transferable to foreign markets (Cuervo-Cazurra \& Genc, 2008). The competition tends to be based on price, not on being as sustainable as technology or brand (Gammeltoft, Barnard, \& Madhok, 2010).

Massive government intervention in business activities is a common feature of emerging economies. Examples are taxation, regulation, and state ownership, mainly in key sectors: mining, energy, infrastructure, and financing. Moreover, poor disclosure, financial opacity, complex organizational structures, weak property rights protection, fragile political institutions, corruption, social tensions, and regulatory distortions are part of the institutional arrangement of emerging economies (Ball et al., 2000; Ramamurti, 2012). The quality of government policies impacts emerging markets firms (La Porta, Lopez-De-Silanes, Shleifer, \& Vishny, 1999), mainly because bureaucrats and politicians can have selfinterests or be corrupts. This characteristic is enhanced in emerging economies, whose national economies have grown rapidly, where industries undergo dramatic structural changes, and whose markets hold promise despite volatile and weak legal systems (Luo \& Tung, 2007). However, emerging economies cannot be generalized, because they include a diverse population of countries. In emerging economies, central and local governments are larger and more active than in developed economies (Gammeltoft et al., 2010).

In this paper, we avoid using the conception of institution introduced by North (1990), by adding a political character to the discussion. Institutions are a set of formal or informal norms (followed by actors for material, cognitive, or normative reasons). Entities, as long-term firms, are formally recognized by their members, whose norms contribute to the political and economic institutions. The government of coordinated market economies has gained advantages, as business associations and trade firms, 
to solve difficulties, as information asymmetry, high transaction costs, and conflicts of negotiation. Once independent of the government and responsible for their members, these institutions are in a better position to acquire trust, monitor relationships and transaction costs, impose sanctions, and coordinate agents (Hall \& Soskice, 2001). However, the agents' compromise will be higher as they influence to punish the government because of any deviation from established agreements (Wood, 1999).

\subsection{Networks from a political perspective of the neo- institutional theory}

The creation and implementation of policies result from the interaction between interests, objectives, and strategies (Scharpf, 1978). Political networks involve participating in networks' decisions and having power and access to the decision-making process. Regardless of how they are aligned, considering the culture of the industry, policies of the industry, and interdependency between the actors of these networks is relevant (Klijn, 2008). Through systematic interactions, players build the rules defining the institutional environment and the new interactions of the network (Klijn, 2001). This relationship is analyzed from the perspective between the government and the market and from the level of the firm.

In a macro-level, from the perspective of government and market, the government determines the structure of the markets, mainly in emerging countries. Business results from the policies and laws created by governments that define the inter-firm relationships (Grant et al., 2010). On the one hand, there is the risk of inefficient allocation of resources due to political interests (Grossman \& Helpman, 1994) and information asymmetry motivated by power relationships. On the other hand, the information asymmetry can reduce costs to obtain information, uncertainty, and risk sharing (Grant et al., 2010). The government accepts this background because needs resources and profits generated by the firms. Therefore, it is necessary that the government attracts and retains business (Lindblom, 1977), mainly through leading firms that enhance the compromise of business networks (Werner \& Wilson, 2008). Government plays a key role in fostering or inhibiting the global insertion of the firms. Governmental policies involve temporary protectionist measures through fees or entry restrictions (Lazzarini, 2015). It acts directly on the market through state-owned multinational firms. In this case, regulations can be applied in favor of the government and at the expense of other shareholders (Cuervo-Cazurra et al., 2014).

In a micro-level, from the analysis of firms, business associations and representatives of the industry create conduct codes, guiding the government practices. These are attempts to fill the gaps left by the government, creating a selfregulation of the businesses through political influences (Dahan, Hadani, \& Schuler, 2013). At this point, dominant actors influence the rules and the other participants of the organizational field, guiding the actions according to their interests (Fligstein, 1996). The nature of the institutions and their environment influences the institutional strategies. By its turn, institutional strategies redesign their competitive positions according to the social structures that legitimize or challenge them to the group. Institutional strategies generate institutional leadership inside the organizational field (Lawrence, 1999). We understand institutions as structures responsible for guiding or restricting the choices of agents, acting in a positive, negative, or indifferent way, aiming to influence its strategic decisions. Institutions affect the firms' decision and enable or hinder the process itself. This relationship affects the industrial competitiveness, according to the proximity of formal institutions and firms of the industry. On the other hand, it is a recursive relationship. It meets the interests of the government, aiming to correct market imperfections, provide resources or protection to some given industries.

\section{METHOD}

From the qualitative bias, our research focuses on a single case study with multiple analysis units. We chose this technique, because it comprises a complex, context-dependent phenomenon (Eisenhardt, 1989), with the networks being an adequate unit to be analyzed following the neoinstitutional theory. The case selected is the Brazilian wine industry, which is adequate because presents three aspects. First, it is in the early stages of internationalization with fragmentation in many business associations and governmental institutions. Second, there is the influence of formal institutions for network formation. Third, there is a high level of 
heterogeneity between firms. Historically, the Brazilian wine industry is marked by aggressive strategies of competition in the domestic market. Recently, the increased competitiveness of Brazilian wines impelled the firms to foreign markets.

In order to analyze the decision-making process under a political bias, of formal institutions in the internationalization process of firms located in an emerging economy, we divided formal institutions into wineries and institutional entities. We chose those wineries because they are members of Wines of Brasil, a project that aims to promote the Brazilian wine in the international market. We considered representation aspects in terms of quality and production of the exported products, in addition to pioneering in the participation in the Wines of Brasil. We divided the wineries based on some criteria. First, we categorized by entry strategy in foreign markets: direct and indirect export, contractual modes, and foreign direct investment. Second, we classified by the stage of internationalization, as not internationalized wineries; some experienced in international markets, wineries with a history of foreign operations, compared to other project participants. In addition, I interviewed wineries' managers who did not join the Wines of Brasil. Similarly, regarding institutional entities, we interviewed representatives presenting relevant information on the Wines of Brasil and the internationalization of wineries.

We applied twenty-three semi-structured interviews with supervisors, managers, and directors of export departments or winemakers of the wineries. From formal institutions, we interviewed managers, researchers, consultants, and industry executives, enabling data triangulation between different accounts of wineries and institutional entities. Examples of open questions were: i) grouping strategies and consolidation in the sector; ii) reasons for the internationalization, benefits, impacts, difficulties; iii) impact of internationalization to conquer the domestic market; iv) perception on formal institutions (private, governmental, class, mixed-source ones); v) institutions can affect the internationalization process of the winery (benefits, restrictions, relevance, difficulties). We recorded and transcribed all the interviews, generating a corpus of about 400 pages and 19 hours of recording of statements given by the respondents. We collected secondary data from electronic sites of the institutions and wineries to complement and contrast information from interviews and bibliographical material. Some examples were statistical data and research on viniculture to generate knowledge about the wine industry. We associated the interviews with the secondary data, our observations, and notes, thus enabling the data triangulation. This strategy helps in the more comprehensive analysis since it takes into account more than one source of information (Flick, 2009). While dealing with primary data and secondary data, we aimed the data triangulation. Such procedures allowed obtaining more validity and reliability when collecting data at different times, from different sources or instruments in the study of one same phenomenon (Collis \& Hussey, 2005; Stake, 1995).

Given the qualitative approach, we considered the validity and reliability of the method carefully. Thus, we based our interview script in three analysis categories. The first category is networks as a source of power. The second category is networks from an economic perspective. This category is networks from a political perspective of the neo-institutional theory (Table 1). We worked with these categories because we believed they were enough to describe the decision-making process adopted by wineries in the domestic market and, considering the support of institutional entities, furthered its internationalization.

Tab. 1

Analysis categories used for the interview script

\begin{tabular}{|c|c|c|}
\hline Categories & Subcategories & References \\
\hline $\begin{array}{c}\text { Networks from an } \\
\text { economic } \\
\text { perspective }\end{array}$ & $\begin{array}{c}\text { Protectionist, } \\
\text { contractual } \\
\text { mechanisms, } \\
\text { economic } \\
\text { incentives, } \\
\text { information } \\
\text { asymmetry, } \\
\text { transaction costs }\end{array}$ & $\begin{array}{c}\text { Dunning \& } \\
\text { Lundan, 2008; } \\
\text { North, 1990; Hall } \\
\text { \& Soskice, } 2001\end{array}$ \\
\hline $\begin{array}{c}\text { Networks from a } \\
\text { political } \\
\text { perspective }\end{array}$ & $\begin{array}{c}\text { Decision-making, } \\
\text { power, political } \\
\text { influence and } \\
\text { interests, } \\
\text { institutional } \\
\text { strategies, } \\
\text { institutional } \\
\text { leadership }\end{array}$ & $\begin{array}{c}\text { Grant et al., 2010; } \\
\text { Dahan et al., } \\
\text { 2013; Fligstein, } \\
\text { 1996; Lawrence, } \\
1999\end{array}$ \\
\hline
\end{tabular}

Source: Developed by the authors.

We considered networks as relevant for sharing resources and results between the firms, providing opportunities and sources of influence and power. 
From the economic and political perspectives, we considered the influence of institutions, as the government, on the networks and firms. For data analysis purposes, we used the content analysis technique in order to infer knowledge through the generation or not of quantitative indicators (Bardin, 2011). We analyzed the data by preparing summaries, interview recordings, in addition to the printed and digital materials. In order to systematize this entire material, we used NVivo software 10.0 to code and categorize the data. Then, we constantly compared the data (Strauss \& Corbin, 1990) between theory and results, leading to a priori and a posteriori analysis of subcategories based on the reorganization of the evidence provided by NVivo. This process enabled to rename some subcategories and exclude others, causing the emergence of the institutional, political decisions as dominant for strengthening the networks. Finally, the results furthered the discussion of the institutional influences on the strategies of inter-firm networks, taking the Brazilian winery industry as a research field.

\section{THE WINE INDUSTRY INTERNATIONALLY AND IN BRAZIL}

Traditionally, the wine producing market is divided into two groups. Countries in the "Old World" are in the North Hemisphere (Germany, Spain, France, Italy, and Portugal), which are nations with tradition in producing and consuming wine. Such countries reduced their world market share in the last years. Countries in the "New World" are mostly in the South Hemisphere (South Africa, Argentine, Australia, Brazil, Chile, New Zealand, and Uruguay) and the United States. These countries have stood out because of the variety of grapes cultivated, the technologies applied in the production of wine, and the relationship strategies they established between wineries. They raised their participation in the world market in production and commercialization and on sale levels. Following the division of the wine international commerce, a systematic movement towards the reduction of the international commerce participation took place in five representatives of the "Old World" compared to the six countries of the "New World." In the 1980s, countries in the "Old

Tab. 2

Wine production (excluding juice and musts).***

\begin{tabular}{|c|c|c|c|c|c|c|c|c|c|}
\hline Unit: $\mathrm{mhl}$ & 2011 & 2012 & 2013 & 2014 & $\begin{array}{c}2015 \\
\text { Provisional }\end{array}$ & $\begin{array}{c}2016 \\
\text { Forecast }\end{array}$ & $\begin{array}{c}2016 / 2015 \\
\text { Variation in } \\
\text { volume }\end{array}$ & $\begin{array}{l}2016 / 2015 \\
\text { Variation in \% }\end{array}$ & Rank \\
\hline Italy & 42.8 & 45.6 & 54.0 & 44.2 & 50.0 & 48.8 & -1.2 & $-2 \%$ & 1 \\
\hline France & 50.8 & 41.5 & 42.1 & 46.5 & 47.4 & 41.9 & -5.7 & $-12 \%$ & 2 \\
\hline Spain & 33.4 & 31.1 & 45.3 & 39.5 & 37.3 & 37.8 & 0.5 & $1 \%$ & 3 \\
\hline United States & 19.1 & 21.7 & 23.6 & 23.7 & 22.1 & 22.5 & 0.5 & $2 \%$ & 4 \\
\hline Australia & 11.2 & 12.3 & 12.3 & 11.9 & 11.9 & 12.5 & 0.6 & $5 \%$ & 5 \\
\hline China* & 13.2 & 13.8 & 11.1 & 11.1 & 11.5 & 11.5 & 0.0 & $0 \%$ & 6 \\
\hline South Africa & 9.7 & 10.6 & 11.0 & 11.5 & 11.2 & 10.5 & -0.7 & $-7 \%$ & 7 \\
\hline Chile & 10.5 & 12.6 & 12.8 & 10.5 & 12.9 & 10.1 & -2.7 & $-21 \%$ & 8 \\
\hline Argentina & 15.5 & 11.8 & 15.0 & 15.2 & 13.4 & 8.8 & -4.6 & $-35 \%$ & 9 \\
\hline Germany & 9.1 & 9.0 & 8.4 & 9.2 & 8.8 & 8.4 & -0.4 & $-4 \%$ & 10 \\
\hline Portugal & 5.6 & 6.3 & 6.2 & 6.2 & 7.0 & 5.6 & -1.4 & $-20 \%$ & 11 \\
\hline Russia* & 7.0 & 6.2 & 5.3 & 4.9 & 4.9 & 4.9 & 0.0 & 0\% & 12 \\
\hline Romania & 4.1 & 3.3 & 5.1 & 3.7 & 3.5 & 4.9 & 1.3 & $37 \%$ & 13 \\
\hline New Zealand & 2.4 & 1.9 & 2.5 & 3.2 & 2.3 & 3.1 & 0.8 & $34 \%$ & 14 \\
\hline Hungary & 2.8 & 1.8 & 2.6 & 2.6 & 2.9 & 2.7 & -0.2 & $-6 \%$ & 15 \\
\hline Greece & 2.8 & 3.1 & 3.3 & 2.8 & 2.5 & 2.6 & 0.0 & $2 \%$ & 16 \\
\hline Serbia* & 2.2 & 2.2 & 2.3 & 2.3 & 2.3 & 2.3 & 0.0 & $0 \%$ & 17 \\
\hline Austria & 2.8 & 2.1 & 2.4 & 2.0 & 2.3 & 1.8 & $-0.6=5$ & $-21 \%$ & 18 \\
\hline Georgia* & 1.1 & 0.8 & 1.0 & 1.1 & 1.7 & 1.7 & 0.0 & $0 \%$ & 19 \\
\hline Moldova* & 1.5 & 1.5 & 2.6 & 1.6 & 1.7 & 1.7 & 0.0 & $0 \%$ & 20 \\
\hline Brazil* & 3.5 & 3.0 & 2.7 & 2.7 & 2.8 & 1.4 & -1.4 & $-50 \%$ & 21 \\
\hline Bulgaria & 1.1 & 1.3 & 1.8 & 0.8 & 1.3 & 1.3 & 0.0 & $1 \%$ & 22 \\
\hline OIV World Total ** & 267.7 & 258.1 & 288.9 & 270.8 & 274.4 & 259.5 & -15.0 & $-5 \%$ & \\
\hline
\end{tabular}

* Report of the year 2015, 2016 figures not yet available.

** OIV estimate: mid-range estimate for evaluation of 2016 world production: from $255.0 \mathrm{mhl}$ to $264.0 \mathrm{mhl}$.

*** Countries for which information has been provided with a wine production of more than $1 \mathrm{mhl}$.

Source: OIV (2016). 
World" had almost $80 \%$ of the wine international commerce. Currently, these countries have up to $60 \%$ of this activity. During the same period, countries in the "New World," rose from 3\% to $28.4 \%$ the world market share. This fraction was taken from the countries in the "Old World" and in the Northwest of Africa and Center-East of Europe. Individually, there is the superiority of countries in the Old World, with Italy, France, and Spain in the first three positions in wine production. Sequentially, countries in the New World have stood out (United States, Australia, South Africa, Chile, and Argentina) (OIV, 2016) (Table 2).

Tab. 3 world that allows for two harvests per year (Voltolini, 2013).

Wineries and entities represent formal institutions in the Brazilian wine industry. Only in the mid-XX century, with greater regulation of the industry, institutional entities of the wine industry are created to lay rules and regulations, typical of formal institutions. At the end of the last century, institutional entities are created, aiming mainly to encourage the internationalization of wine, based on product differentiation achieved with geographical indication and, recently, with the designation of

Estimation of Wine Production in 2012 (Lts.)

\begin{tabular}{cccc}
\hline & Non-vinifera wines & Vinifera wines & Total \\
\hline Rio Grande do Sul & $214,359,363$ & $52,822,277$ & $267,181,640$ \\
Santa Catarina & $25,200,000$ & 808,000 & $26,008,000$ \\
Paraná & 750,000 & 100,000 & 850,000 \\
São Paulo & $4,000,000$ & 100,000 & $4,100,000$ \\
Minas Gerais & $3,500,000$ & 10,000 & $3,510,000$ \\
Goiás & 280,000 & 2,100 & 282,100 \\
Pernambuco/Bahia & $2,000,000$ & $6,000,000$ & $8,000,000$ \\
\hline Total & $250,089,363$ & $59,842,377$ & $309,931,740$ \\
\hline
\end{tabular}

Brazil is the 13th consumer of wine and the 15th wine producer in the world. Despite the industry's fragmentation, few firms concentrate most of the production and account for the internationalization of products that historically always competed based on leadership in the total cost. Only recently, through the creation and dissemination of an identity of Brazilian wine abroad, the industry begins competing based on differentiation of its products. However, obstacles remain to transform national wineries in internationally competitive firms, such as macroeconomics, climate, and coordination difficulties. Macroeconomic difficulties referred to changes in macroeconomic policies and an exchange rate. Climate difficulties affected the average annual growth of rain and high humidity. Coordination difficulties reflected the large industrial spray in small business and the large number of representative institutions in the industry (Farias, 2011).

As in the grape cultivation, Rio Grande do Sul has more than $85 \%$ of the wine production in Brazil. However, only about $20 \%$ of those correspond to fine wines, with the others being table wines. Proportionally, Bahia and Pernambuco with the Rio São Francisco valley stand out. Even with an incipient production, $75 \%$ is directed to fine wines (Table 3 ). This region is one of the few regions in the entire origin. Thus, formal institutions play a critical role in the evolution and consolidation of the wine industry in Brazil. Moreover, through the relationship strategies promoted by these entities, based on the participation of wineries, significant advances in the internationalization of the firms were made.

\subsection{Wineries}

Historically, a diversity of firms characterizes the wine industry in Brazil. From the interviews, we collected the testimonies of four largest wineries - Salton, Aurora, Casa Valduga, and Miolo - in order to have a richer context to explore. Most of the smaller wineries were created in the 1970s. In the 1980s with the expansion of the Brazilian table wine, grape cultivation in family enterprises started in similar times. However, the difference between currently relevant firms is transforming the family activity into a business initiative while seeking the internationalization of its products.

Dealing with the duality between family tradition and productive, commercial professionalism is the challenge of the wineries. The preservation of identity and family history differentiates the product; qualifying the grape growing process, production, and commercialization of wine adds value to the 
wine. The winery owner must perceive that sells a product and a brand, an image, and in that image appears the whole a story that adds value to the wine.

\subsection{Institutional entities}

The Brazilian wine industry stands out for the large amount of representative institutional entities consolidated over the years. Institutional entities were created or engaged to fill the gap in knowledge, techniques, regulations, legislation. Such entities encouraged the growth of the wine industry in the South of Brazil. The first to engage was the Brazilian Corporation for Agricultural Research (Embrapa). Embrapa provided skills and knowledge to the farmers. The second was the Federation of Industries of Rio Grande do Sul state (Fiergs). Fiergs promoted the association of wineries in this industry. In 1998, the Brazilian Wine Institute (Ibravin) was founded. Ibravin goal was to promote a qualification work and promotion of the region, aimed at developing all production chain of grape and wine, providing an exponential evolution of the wine industry in Brazil.

Furthermore, in 2002, the Integrated Sector Project Wines of Brazil was established through an export consortium organized by Fiergs. At that moment, it was composed by six wineries, Casa Valduga, Aurora, Lovara, Salton, Miolo, and De Lantier. That export consortium aimed to start the internationalization through planning, market researching and developing initial experiences in exports. The consortium promoted international courses, meetings, fairs, and events. In 2004, supported by the Brazilian Trade and Investment Promotion Agency (Apex-Brasil), the export consortium became an integrated sector project. Such integration started through an agreement with Ibravin, aiming to promote the Brazilian wine in the international market.

Wines of Brasil supported 50 participating wineries in a range of aspects. Financially, Wines of Brazil supports by subsiding firm's exhibition on international events. On knowledge, Wines of Brazil developed studies about target markets. On learning, Wines of Brasil trained people to act in the international market by agreements with service providers to sample, to understand customs clearance standards, to purchase air tickets, among other activities related to the external market.

\section{Wines of Brasil under a Political-Economic Bias}

Like other industries in the global agribusiness, from 2000s global wine industry is characterized by increasing competition between economic blocs, especially business clusters based on intensive knowledge of technology and management. The participation of governmental actors is crucial, fostering strategic relationships between national firms and international markets, aimed at economic and social development of the wine-producing regions imperative (Protas, Camargo, \& Mello, 2013).

Firstly, the relationships network formed in the internationalization process - in most cases, through industry entities - helps in shaping marketing strategies for larger Brazilian wineries. Unlike firms operating only in Brazil, internationalized wineries can reach new levels of learning, transposing them into their domestic operations. Regarding this issue,

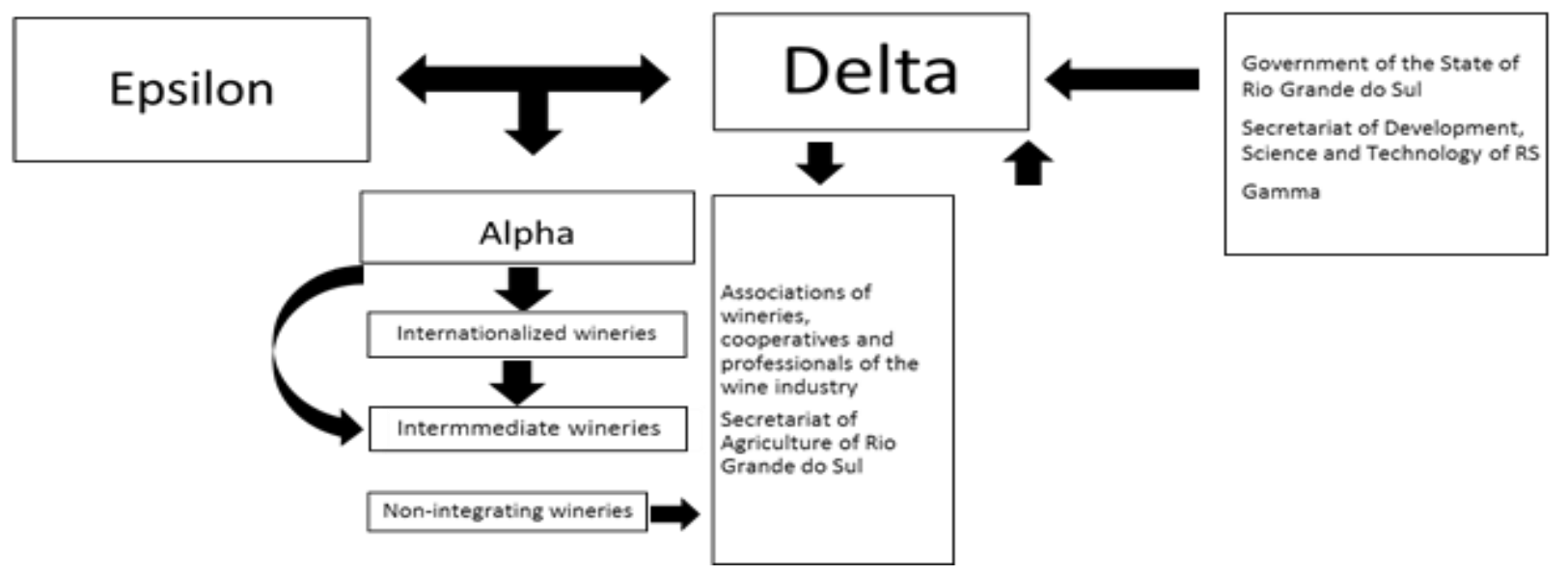

Fig. 1

Structure of the Wine Industry based on Wines of Brasil.

Source: Developed by the authors. 
actors can have objectives and access to different sources of power while shaping the collaboration according to their interests, in order to influence the results (Lotia \& Hardy, 2008). The presence of Brazilian wines in foreign markets generates gains for the industry participants. There are exchanges of experience, learning gains, and expansion of the relationships network by contact with more experienced wineries and entities. In addition, this engagement between wineries and entities created strategic options, reducing the dependence on the domestic market. Another gain was the recognition by the Brazilian consumer as the national wine had prestige and international awards. Finally, the experience established new relationship strategies, highlighting the collaboration in foreign markets.

On the other hand, we noticed in the Brazilian wine industry a division into numerous institutional entities that represent conflicting or converging interests. Ibravin, being an aggregating entity of the industry, seeks a rapprochement with other formal institutions towards a common goal, the project Wines of Brasil. This entity assumed the role that until then was Fiergs', but dealt with limitations for managing projects in many industries of Rio Grande Sul. At times, Wines of Brazil is mistaken for the proponent entity, Ibravin, due to its organizational proximity. If, on one hand, this can be positive, since Ibravin has an institutional leadership in the industry, on the other hand, management conflicts can occur, even though having similar or common objectives. The evidence is that the Brazilian Grape and Wine Union (Uvibra), in 2007, left the Deliberative Board of Ibravin, due to disagreement with the decision taken, but returned in 2009, according to the Office of Uvibra. Nonetheless, Ibravin was mentioned unanimously by wineries and other institutional entities as a formal institution with a positive influence on the internationalization process and within the project Wines of Brazil. Ibravin stands out in promoting a systematic and collective learning within the wine industry, through the systematic exchange of knowledge and experiences. For these results, it had to be legitimized among firms through a transition that was planned and conducted in a harmonious way. Hence, the entity would take over the management of Wines of Brazil, until then under the responsibility of Fiergs. Moreover, continuity and evolution of the results were essential for the institution to assume a leading position in this industry. These reports exposed institutional thickness in many senses. Firstly, there are strong and numerous entities. Secondly, there are high rates of interaction between entities and the region. Thirdly, there is evidence of the rising of dominant institutions and collective representatives by coalitions. Fourthly, there is evidence of the development of a mutual conscience (Amin \& Thrift, 1994). In the interviews, the importance of ApexBrazil is emphasized, especially for the financial support provided. In some cases, technical studies and knowledge brought to the industry, in particular for the larger wineries, were mentioned. In many emerging economies, central and local governments are in line with the priorities of firms, providing financial subsidies and other media (Gammeltoft et al., 2010). The central feature acquired by wineries through the Wines of Brazil is the knowledge of the steps of the internationalization process, generating a learning that is widespread within the network. This strategic resource starts with the grape growth within the standards recommended by the international market and continues the wine-making process, product commercialization, and marketing and internationalization strategies.

Even non-internationalized wineries believe in Wines of Brazil and the actions being implemented, generating visibility in the international and in the domestic markets. Thus, while not participating in the Wines of Brazil, earnings are appropriated by firms with less investment capacity resources in this project. However, these benefits are restricted due to limited interaction within the network, with little or no interaction with the other institutional entities and other wineries (Figure 1). However, firms must deal with weak institutions in these markets, which are subject to protectionist mechanisms that incur higher transaction costs (Mesquita \& Lazzarini, 2008).

Secondly, considering networks from the economic perspective, in the Brazilian context, internationalization is considered by smaller Brazilian wineries as an option, due to resource constraints. However, its international expansion increases its competitiveness in the domestic market, considering the learning and the recognition that the consumer attaches to exported wine. It decreases the dependence on the local market, creating strategic options and a more diversified customer basis.

A major problem is the small-scale production of the Brazilian wine industry. Thus, there are opportunities for imported products, mainly for 
countries with an export vocation in this industry, like the ones that are neighboring with Brazil. The representative of Don Giovanni mentioned the case of Chile, which exports $80 \%$ of the wine it produces, assuming a prominent position on the world wine scene. It is a paradigm for Brazilian wineries, especially the smaller ones, which compose most of the domestic industry. They must strengthen their brand and the image of Brazil through internationalization and fight for space in the local market. As an aggravating, there are bilateral agreements negotiated between countries. Such agreements are known as "basket of products" where tax exemption is offered for Brazilian imports. There is a reduction of aliquots on Chilean imports for Brazilian automobiles, pieces, machinery, electronic devices, and meat. By its turn, Chile got reduced aliquots to export wines, chemical products, and salmon to Brazil (ALADI, 2015). The interests of the government in political-economic, international negotiations do not always correspond to the interests of the firms. In this case, we consider the comparative institutional advantages of their nation's economy. Governments support initiatives that do not interfere with the competitive advantage their firms enjoy (Hall \& Soskice, 2001).

A controversial issue, addressed during the interviews, was the safeguard clause. According to the interviewee from Salton, initially the safeguard clause should create a protection only against the import of Chilean wines. However, the initiative caused a movement of the main importers against local wineries, as they felt under pressure. The interviewee observed that Ibravin delayed in taking a position, generating more dissatisfaction and uncertainties. The consultant at Aprovale agrees that this clause has not been sufficiently explained to the market. However, the low-scale production of the national wine industry could be compensated with a bigger offer of imported wines. It could stimulate the rise of the consumption per capita in Brazil. When withdrawing the safeguard application, the challenge is to redesign the relationship between producers and the retailer network, creating policies that can stimulate the marketing of domestic wine. There will have to be a greater cooperation between wineries, aiming to contemplate the industry objectives, instead of specific negotiations.

Aiming to exhibit the main findings of our research, Table 4 shows quotes of representatives that are examples of discourses of the participants in the Brazilian wine industry.

As the last, considering the political perspective of networks, we identified three main discourses based on several reports. Firstly, according to the representative of Embrapa, Wines of Brazil is part of a society that is not entirely qualified, in terms of human, financial, and logistical resources. Even with all incentives and benefits, non-compliance of the wineries is due to the interpretation as an elitist project that favors the larger wineries. This perception increases the gap between large and lower-production wineries. According to Lawrence (1999), the nature of the institutions and their environment influences the institutional strategies. In its turn, there is a redesign of their competitive positions according to the social structures legitimizing or challenging them before the group. Collaboration represents political movements of firms to protect their privileged positions and excludes the weaker interested parts (Lotia \& Hardy, 2008). It is evidenced by the fact that some smaller wineries admit not having organizational resources enough to be committed to the project. Thus, they choose to work only in the local market (Dal Pizzol and Casa Venturini). Secondly, according to the managers of larger wineries (Casa Valduga) or smaller wineries (Basso and Don Giovanni) - that already had exported - , there are programs for inserting smaller wineries in the internationalization process. Even with the restriction of resources, they face the challenges imposed by the internationalization process, but probably refute the practice norms and the political decisions in an institutional arrangement. Finally, a third vision, from a specialist in the wine industry, would place Wines of Brazil as a sort of incubator where larger wineries develop competencies. Through the development of sources of competitiveness, they would leave more resources to other firms. Nonetheless, through political decisions, it is important that Wines of Brazil has significant results biannually, so that the government renews their consortium and resources investment through Apex-Brasil. This occurs through the participation of large firms, even if they are not the ones most in need of resources. The power perspective in a network aims to reach their goals, by helping to function effectively (Gulati et al., 2000), even if they replace one part in detriment of another to keep the stability (Child \& Faulkner, 1998). 
Tab.4

Discourse of the participants of Brazilian wine industry

\begin{tabular}{ll}
\hline SUBCATEGORIES & NETWORKS FROM AN ECONOMIC PERSPECTIVE \\
\hline Protectionist & "I believe that the attempt to sell the safeguard was not successful, (...) but it would have been important. \\
& I think what's being done in Brazil is a counter-attack now. As we said, Brazil is a small global player. \\
& Consultant at Aprovale) \\
Economic incentives & "The sector (...) is still relatively fragile (...). It is too regionalized, concentrated, we depend a lot on the \\
& private initiative. So since it is not so representative of the Brazilian economy, the support sometimes, \\
& especially from the government, ends up not being enough. (Exportation Coordinator at Salton) \\
& "Today, if Aurora has reached so far is thanks to Ibravin. Along with the firms, of course, and the Apex \\
& sponsorship, right? [...] It is Apex that pays for the exhibition stands, installation. (...)." (Exportation \\
& Supervisor at Aurora winery) \\
& "I think the work of Apex, (...) gives an extra support to the exporter (...) Imagine if I had to make a market \\
& survey, in order to select which markets (...)." (International Relationships Manager at Miolo) \\
& "So we have the Apex support through Wines of Brasil, which is essential not only to carry out the \\
& resources but also the events through the resources, including the entire team that supports us, right? \\
& {$[\ldots]$ If we had more resources, could we do much more things? Yes, we could do so much more." } \\
& (Exportation Coordinator at Salton)
\end{tabular}

Decision-making power

Political influence and interests

Institutional strategies

\section{NETWORKS FROM A POLITICAL PERSPECTIVE}

"The internationalization process (...) depends on (...) effort and investment, invariably. Why do I have small firms that have a large volume of exports? They don't receive much investment, but they have much effort, and this pays off, and this is very easy to analyze, why can't a larger firm export as much? Because although it receives much investment, it is not making enough effort into the business. So, I think that this is the balance. (...) obviously, a larger firm is either more involved, or it benefits from a larger number of actions and it is the one that stands out in the end." (Exportation Manager at Wines of Brasil)

"I think we have the large wineries, those that already have an established name, work in the international market, receive awards, and then we have the other ones. Among them, I think that there is a competition, but this competition is beneficial, anyway. I think we should be more open on the medium-sized ones (...) And what I know is that we are with Wines of Brasil. A brand is being established. Very good!" (Business Promotion Director at FIERGS)

"The role of Ibravin (...) what they have to do is (...) make the firm get together and discuss the problems we face, for instance, we send projects to Brasilia, to discuss and to put the fiscal stamp, control the contraband, in short, this sort of things that are started out by Ibravin." (Exportation Supervisor at Aurora winery)

"We work with Ibravin, but also directly with the firms. In general, our calendar of fairs is based on the demands of the sector [...] Once there was a culture in the State that it should only be impartial and that this impartiality was only given through the entities. (...) in practice, we have been noticing that entities sometimes disclose, but they also don't publicize the actions we do." (Business Promotion Director at Secretariat for Economic Development, Science and Technology of Rio Grande do Sul)

"And this should be passed on to the national associations. We understand here that the legitimate entity that could sustain this project was Ibravin. It has Fundovitis, and other funds, which could complement any other existing activity in the Apex project." (International Relationships and Trade Manager at FIERGS)

Source: Elaborated by the authors

\section{FINAL CONSIDERATIONS}

Based on our empirical study, we were able to analyze political influences in the decision-making by formal institutions in the internationalization process of firms located in an emerging economy. In this context, we observed how the institutions play a role in the decision of the wineries regarding the internationalization process. This happens when they allow the participation in fairs abroad, empower wineries to the activities of foreign trade, or develop market research and business rounds. Thus, we developed some contributions from this study.

Firstly, as a managerial contribution, wineries understand that, even in a small proportion, internationalization benefits the industry as a whole. Internationalization brings visibility to the Brazilian wine, increasing the competitiveness of national firms, domestically and internationally. Dealing with 
competition against foreign wines, mainly South American wines, is apparently the major challenge. In the case of the wine industry, internationalization is induced by formal institutions to promote building relationships while leveraging learning within the network. Thus, firms acquire sources of competitiveness to compete in markets internationally. Non-market strategies (social, political, and legal arrangements) can be associated with the competitive forces in order to create opportunities for firms (Baron, 1995). Secondly, firms must adapt to the institutional changes in order to grow (Martin, 2014). One of these changes is how to obtain legitimacy in the domestic market and external market, moving from one to another (Kostova \& Zaheer, 1999). In the case of Wines of Brazil, the wineries seek to establish an image of Brazilian wine in the international market, adding legitimacy to the product in the domestic market. Institutions, in turn, increase the competitiveness of their firms through subsidies, protectionist measures, financial incentives, or organizational restructuring. Firms must carry out institutional arbitration with the support of institutions while avoiding structural deficiencies of the domestic environment and seeking advantages in the international market (Boisot \& Meyer, 2008).

Thirdly, as an academic contribution, as institutions, from a political perspective, can influence positively an industry, the opposite is true. The government cannot afford resources to benefit or protect all the industries, and cannot provide incentives to all firms. Those supported by this will lose competitiveness. Firms must adjust to the development of multi-level systems of government, with political settings being one of the strongest influences on how firms develop their strategies (Grant et al., 2010). Moreover, we must consider that such pressures do not pertain to all institutions in a homogeneous way. Institutions vary across different locations in the same country. Pressures are asymmetric too, depending on the origin, form, and objective of the pressure. Policymakers must recognize that what is good for the national economy is not necessarily beneficial for the institutional framework, because there are different ways to reach a goal.

Understanding the duality for institutions to provide or not incentives for an industry is a challenge for scholars. Some authors focus on the role of the home country institutions and in particular on the role of government in shaping the process of internationalization of domestic firms (Ramamurti, 2008). Our focus was on the motivations for formal institutions to foster the internationalization of firms in emerging countries. We analyzed the decisionmaking process as a previous step in the choices of the industries and motivations of the industries. For the firms, the choices are based on trying to achieve economic advantages through political influences. For the institutions, the choices are made based on political influences considering institutional strategies.

For future research, we suggest expanding the data collection in that industry. This study did not include all entities and wineries involved in the institutional environment. Another potential line of research is to explore connections between actors of this industry through social capital, considering both structure and quality of the ties.

Despite our contributions, our study is subject to boundary conditions. First, regarding the case study method, although it approached researchers to their study object, there is always the risk that it is just a mere description of the phenomenon, and it cannot be generalized to large samples. Second, the analysis was subject to the respondents' perception of the survey instrument, and that of the researchers in relation to the results obtained, which can produce failures or inferences. Third, institutional pressures are dynamic and asymmetric. We do not evaluate the dynamism of the institutional change and the evolution of the relationships between government, firms, and institutions. Finally, researchers must understand top-down models of institutional effects and the institutional process that incorporates institutional influence and firm responses (Scott, 2001). Thus, we believe that our study is another step towards this path to be followed.

\section{REFERENCES}

- Associação Latino-Americana de Integração (ALADI). (2015). Foco ALADI: Oportunidades comerciais BrasilChile, 03, 1/11.

- Amin, A., \& Thrift, N. (1994). Living in the global. In A. Amin, \& N. Thrift (Eds.), Globalization, Institutions and Regional Development in Europe. Oxford: Oxford University Press.

- Ball, R., Kothari, S.P., \& Robin, A. (2000). The effect of international institutional factors on properties of accounting earnings. Journal of Accounting \& Economics, 29, 1-52. 
- Anand, B.N., \& Khanna, T. (2000). Do firms learn to create value? The case of alliances. Strategic Management Journal, 21(3), 295-315.

- Banerjee, A., Banerji, R., Duflo, E., Glennerster, R., \& Khemani, S. (2006). Can Information Campaigns Spark Local Participation and Improve Outcomes? A Study of Primary Education in Uttar Pradesh, India. World Bank Policy Research, n. 3967.

- Bardin, L. (2011). Análise de conteúdo. São Paulo: Edições 70.

- Baron, D.P. (1995). Integrated strategy: Market and nonmarket components. California Management Review, 37(2), 47-65.

- Boisot, M., \& Meyer, M. (2008). Which Way Through the Open Door? Reflections on the Internationalization of Chinese Firms. Management and Organization Review, 4(3), 349-365.

- Brey, N.K., Camilo, S.P.O., Marcon, R., \& Bandeira-deMello, R. (2014). Conexões políticas em estruturas de propriedade: o governo como acionista em uma análise descritiva. RAM. Revista de Administração Mackenzie (Online), 15, 98-124.

- Burt, R.S. (1992). Structural holes: The social structure of competition. Cambridge, MA: Harvard University Press.

- Child, J., \& Faulkner, D. (1998). Strategies of Cooperation: Managing Alliances, Networks and Joint Ventures. Oxford: Oxford University Press.

- Child, J., \& Rodrigues, S.B. (2005). The internationalization of Chinese firms: a case for theoretical extension?. Management and Organizational Review, 1, 381-410.

- Collis, J., \& Hussey, R. (2005). Pesquisa em administração. 2nd ed. Porto Alegre: Bookman.

- Cropper, S., Ebers, M., Huxham, C., \& Ring, P.S. (2014). Introdução às relações interorganizacionais. In $\mathrm{S}$. Cropper, M. Ebers, C. Huxham, \& P.S. Ring (Eds.), Handbook de Relações Interorganizacionais da Oxford (pp. 3-28). Porto Alegre: Bookman, 2014.

- Cuervo-Cazurra, A., \& Genc, M. (2008). Transforming disadvantages into advantages: developing-country MNEs in the least developed countries. Journal of International Business Studies, 39(6), 957-979.

- Cuervo-Cazurra, A., Inkpen, A., Musacchio, A., \& Ramaswamy, K. (2014). Governments as owners: Stateowned multinational companies. Journal of International Business Studies, 45(8), 919-942.

- Dahan, N.M., Hadani, M., \& Schuler, D.A. (2013). The Governance Challenges of Corporate Political Activity. Business \& Society, 52(3), 365-387.

- DiMaggio, P., \& Powell, W. (1983). The iron cage revisited: Institutional isomorphism and collective rationality in organizational fields. American Sociological Review, 48, 147-160.
- Dunning, J.H., \& Lundan, S.M. (2008). Multinational enterprises and the global economy. Cheltenham: Edwar Elgar.

- Edwards, T., Delbridge, R., \& Munday, M. (2005). Understanding Innovation in Small and Medium-Sized Enterprises: A Process Manifest. Technovation, 25, 1119-1127.

- Eisenhardt, K.M. (1989). Building theories from case study research. Academy of Management Review, 14(4), 532-550.

- Farias, C.V.S. (2011). Inovação e ganhos competitivos na vitivinicultura gaúcha: uma abordagem preliminar. Anais do 6o Congresso do Instituto Franco-Brasileiro de Administração de Empresas, Franca, SP, Brasil.

- Flick, U. (2009). Desenho da pesquisa qualitativa. Porto Alegre: Artmed.

- Fligstein, N. (1996). Markets as politics: a politicalcultural approach to market institutions. American Sociological Review, 61, 656-673.

- Frieden, J.A. (1991). Invested Interests: The Politics of National Economic Policies in a world of global finance. International Organization, 45(4), 425-451.

- Gammeltoft, P., Barnard, H., \& Madhok, A. (2010). Emerging multinationals, emerging theory: macro and micro-level perspectives. Journal of International Management, 16, 95-101.

- Granovetter, M. (1973). The Strength of Weak Ties. A Network Theory Revisited. American Journal of Sociology, 78(3), 3-30.

- Grant, W., Coen, D., \& Wilson, G. (2010). Political Science Perspectives on Business and Government. APSA 2010 Annual Meeting Paper.

- Grossman, G., \& Helpman, E. (1994). Protection for Sale. American Economic Review, 84(1), 833-850.

- Gulati, R., Nohria, N., \& Zaheer, A. (2000). Strategic Networks. Strategic Management Journal, 21(3), 203215.

- Hall, P.A., \& Soskice, D. (2001). Varieties of capitalism: the institutional foundations of comparative advantage. New York: Oxford University Press.

- Hall, P., \& Taylor, R. (1996). Political science and the three new institutionalisms. Political Studies, 44, 936957.

- Instituto Brasileiro Do Vinho (Ibravin). (2013). Site. Retrieved from: http://www.ibravin.org.br

- Jarillo, J.C. (1988). On strategic networks. Strategic Management Journal, 9(1), 31-41.

- Klijn, E.H. (2008). Policy and Implementation Networks: Managing Complex Interactions. In S. Cropper, C., Huxham, Ebers, M., \& Ring, P.S. The Oxford Handbook of Inter-Organizational Relations (pp. 118-146). Oxford: Oxford University Press.

- Klijn, E.H. (2001). Rules as Institutional Context for Decision Making in Networks: The Approach to Postwar 
Housing Districts in Two Cities. Administration \& Society, 33, 133-164.

- Kostova, T., \& Zaheer, S. (1999). Organizational legitimacy under conditions of complexity: the case of multinational enterprise. Academy of Management Review, 24(1), 64-81.

- Lawrence, T.B. (1999). Institutional Strategy. Journal of Management, 25(2), 161-188.

- Lazzarini, S.G. (2015). Strategizing by the government: can industrial policy create firm-level competitive advantage? Strategic Management Journal, 36, 97-112.

- La Porta, R., Lopez-De-Silanes, F., Shleifer, A., \& Vishny, R.W. (1999). The quality of government. Journal of Law, Economics and Organization, 15, 222-279.

- Lindblom, C.E. (1977). Politics and Markets: The World's Political Economic Systems. New York: Basic.

- Lotia, N., \& Hardy, C. (2008). Critical perspectives on collaboration. In S. Cropper, C. Huxham, M. Ebers, \& P.S. Ring. The Oxford Handbook of Inter-Organizational Relations. Oxford: Oxford University Press.

- Luo, Y., \& Tung, R.L. (2007). International expansion of emerging market enterprises: A springboard perspective. Journal of International Business Studies, 38, 481-498.

- Marcon, R., Lazzarini, S.G., Musacchio, A., \& BandeiraDe-Mello, R. (2015). What Do State-Owned Development Banks Do? Evidence from BNDES, 200209. World Development, 66, 237-253.

- Martin, X. (2014). Institutional Advantage. Global Strategy Journal, 4(1), 55-59.

- Mesquita, L.F., \& Lazzarini, S.G. (2008). Horizontal and Vertical Relationships in Developing Economies: Implications for SMEs' Access to Global Markets. Academy of Management Journal, 51(2), 359-380.

- Meyer, K.E., \& Peng, M.W. (2005). Probing theoretically into Central and Eastern Europe: transactions, resources, and institutions. Journal of International Business Studies, 36, 600-621.

- Milner, H.V. (1997). Interests, Institutions, and Information: Domestic Politics and International Relations. Princeton: Princeton University Press.

- Minh, T.T., \& Hjorts $\varnothing$, C.N. (2015). How institutions influence SME innovation and networking practices: The case of Vietnamese agribusiness. Journal of Small Business Management, 53(S1), 209-228.

- Musacchio, A., Lazzarini, S.G., \& Aguilera, R. (2015). New Varieties of State Capitalism: Strategic and Governance Implications. Academy of Management Perspectives, 29, 115-131.

- North, D.C. (1990). Institutions, institutional change and economic performance. Cambridge: Cambridge University Press.
- Organisation Internationale de la Vigne et du Vign (OIV). (2012). Statistical Report on World Vitiviniculture 2012. Retrieved from: http://www.oiv.int

- Peng, M.W. (2002). Towards an institution-based view of business strategy. Asia Pacific Journal of Management, 19, 251-267.

- Pittaway, L., Robertson, M., Munir, K., Denyer, D., \& Neely, A. (2004). Networking and innovation: A systematic review of the evidence. International Journal of Management Reviews, 5/6(3/4), 137-168.

- Protas, J.F.S., Camargo, U.A., \& Mello, L.M.R. (2013). A vitivinicultura brasileira: realidade e perspectivas. Bento Gonçalves: Embrapa Uva e Vinho.

- Provan, K.G., \& Kenis, P. (2007). Modes of Network Governance: Structure, Management, and Effectiveness. Journal of Public Administration Research and Theory, 18, 229-252.

- Ramamurti, R. (2008). What Have We Learned about Emerging Market MNEs? In R. Ramamurti, \& V. Singh. (Eds.), Emerging Multinationals from Emerging Markets. Cambridge: Cambridge University Press.

- Ramamurti, R. (2012). Competing with emerging market multinational. Business Horizon, 55, 241-249.

- Scott, W.R. (1995). Institutions and organizations. London: Sage Publications.

- Scott, W.R. (2001). Institutions and organizations. London: Sage Publications.

- Sena, T., Lana, J., Marcon, R., \& Bandeira-De-Mello, R. (2016). A influência da conexão política nos ativos intangíveis. Brazilian Journal of Quantitative Methods Applied to Accounting, 3, 32-51.

- Sheth, J.S. (2011). Impact of Emerging Markets on Marketing: Rethinking Existing Perspectives and Practices. Journal of Marketing, 75(4), 166-182.

- Scharpf, F.W. (1978). Interorganizational Policy Studies: Issues, Concepts and Perspectives. In K.I. Hanf, F.W. Scharpf (Eds.), Interorganizational policy making: Limits to coordination and central control (pp. 345-370). London: Sage.

- Stake, R.E. (1995). The art of case study research. Thousand Oaks, CA: Sage.

- Strauss, A., \& Corbin, J. (1990). Basics of qualitative research: Grounded theory procedures and techniques. Newbury Park, CA: Sage.

- Theilen, K., \& Steinmo, S. (1992). Historical institutionalism in comparative perspective. In $\mathrm{S}$. Steinmo, K. Theilen, \& F. Longstreth. (Eds.), Structuring Politics: historical institutionalism in comparative perspective. Cambridge: Cambridge University Press.

- Voltolini, A. (2013). (Ed.), Revista Anuário Vinhos do Brasil. Rio de Janeiro: Intergraf.

- Werner, T., \& Wilson, G.K. (2008). Interest Groups. In D. Caramani (Ed.), Comparative Politics. Oxford, UK: Oxford University Press. 
- Wood, S. (1999). Building a Governance Structure for Training? Employers, Government and the TEC Experiment in Britain. In P.D. Culpepper, \& D. Finegold. The German skills machine: sustaining comparative advantage in a global economy (pp. 363-402). New York: Berghahn Books.

\section{About the authors}

- Jefferson Marlon Monticelli - Ph.D Student in Business Administration from the Universidade do Vale do Rio dos Sinos - Unisinos (2017). Master degree in Business Administration from the Universidade do Vale do Rio dos Sinos - Unisinos (2013). Associate Professor of the Graduate Program in Management at Universidade LaSalle - Unilasalle. Research field: Coopetition, International Business and Family Business. E-mail: jefffmarlon@hotmail.com

- Ivan Lapuente Garrido - Postdoctoral Studies at Florida International University - FIU (2014); Doctorate in Business Administration from the Universidade Federal do Rio Grande do Sul UFRGS (2007). Associate Professor of the Graduate Program in Management at Universidade do Vale do Rio dos Sinos - UNISINOS. Research field: Strategy and International Business. Email: igarrido@unisinos.br

- Sílvio Luís de Vasconcellos - Post-doctoral fellow in Business, University of Vale do Itajaí, Brazil. Ph.D at UNISINOS, in 2016, the same university where he got his Master degree in 2012. He acts as teacher at Faculdade Novo Hamburgo (Novo Hamburgo/Brazil) where he teaches international business, strategy and entrepreneurship. He teaches in MBA courses in many universities in the south of Brazil. In parallel, he has a business carrier assisting firms to go global since 1990.E-mail: silviolvasconcellos@gmail.com 


\title{
Perspectivas políticas de redes de relacionamento para a internacionalização de firmas em um país emergente
}

\author{
Jefferson Marlon Monticelli ${ }^{A}$, Ivan Lapuente Garrido ${ }^{A}$ e Sílvio Luís de Vasconcellos ${ }^{B}$ \\ ${ }^{A}$ Universidade do Vale do Rio dos Sinos - UNISINO/RS, São Leopoldo, RS, Brasil \\ ${ }^{B}$ Universidade do Vale do Itajaí, Biguaçu, SC, Brasil
}

\section{DETALHES DO ARTIGO}

\section{Histórico do artigo:}

Recebido em 11 de novembro de 2016

Aceito em 24 de julho de 2017

Disponível online em 31 de agosto de 2017

Sistema de Revisão "Double Blind Review"

Editor científico:

Ilan Avrichir

\section{Palavras-chaves:}

Redes de relacionamento

Teoria neoinstitucional

Perspectiva política

Internacionalização

Países emergentes

\begin{abstract}
RESUMO
A teoria neoinstitucional tem sido usada para explicar fenômenos relacionados a redes interorganizacionais nas perspectivas econômicas e sociológicas. A perspectiva política com frequência não é usada para estudar contextos institucionais de redes. Temos o objetivo de analisar o processo de tomada de decisão das instituições formais no processo de internacionalização de firmas em um país emergente a partir de um viés político. Para o campo empírico do estudo, consideramos a indústria vinícola brasileira. Partindo de um estudo de caso com vinte e três entrevistas com representantes de vinícolas e entidades dessa indústria, nosso artigo visa compreender como as instituições influenciam a internacionalização de firmas em um país emergente. Com base na perspectiva política da teoria neoinstitucional, nosso estudo descreve como as instituições, principalmente o governo, podem influenciar uma indústria. O governo não pode arcar com os recursos para beneficiar ou proteger todas as indústrias, tampouco não pode oferecer incentivos a todas as firmas, e aqueles que não têm apoio perderão competitividade. Para as firmas, as escolhas são baseadas na tentativa de obter vantagens econômicas por meio de influências políticas. Para as instituições, as escolhas são baseadas em influências políticas considerando estratégias institucionais.
\end{abstract}

(C) 2017 Internext | ESPM. Todos os direitos reservados!

To cite this article:

Monticelli, J. M.; Garrido, I. L; Vasconcellos, S. L. (2017). Political perspectives of relationship networks to internationalization of firms in an emerging economy. Internext - Revista Eletrônica de Negócios Internacionais, 12 (2), 74-89. DOI: http://dx.doi.org/10.18568/1980-4865.12274-89

To access this article: $h t t p: / / d x . d o i . o r g / 10.18568 / 1980-4865.12274-89$ 